\title{
A IMPOSSIBILIDADE DE TRIBUTAÇÃO COM ARRIMO EM DEPÓSITOS BANCÁRIOS
}

\section{PARECER}

\section{DA CONSULTA}

Fomos consultados pelo Sr. sobre a legalidade de autuação da Receita $\mathrm{Fe}$ deral, fundada em movimentação de conta bancária, vis a vis sinais exteriores de riqueza.

Refere-se a autuação que deu origem ao litígio que será submetido ao Conselho de Contribuintes, a suposta infringência dos arts. $1^{\circ}$ a $3^{\circ}$ e parágrafos e art. $8^{\circ}$, da Lei $n^{\circ}$ 7.713/88; arts. $1^{\circ}$ a $4^{\circ}$, da Lei $n^{\circ} 8.134 / 90$; art. $6^{\circ}$ e $\S \S$, da Lei $n^{\circ} 8.021 / 90$ e art. 728 , II, do Regulamento do Imposto de Renda aprovado pelo Decreto $85.450 / 80$ (RIR/80), aplicando a cada suposta infração a penalidade prevista, porque, segundo o nobre julgador, em síntese,

"Os rendimentos recebidos de pessoas jurídicas, decorrente do trabalho sem vinculo empregatício quando não declarados, caracterizam-se omissão de rendimentos sujeitos à tributação do imposto de renda da pessoa física através de procedimento de lançamento de oficio;

São tributáveis as quantias correspondentes ao acréscimo patrimonial da pessoa física quando esse acréscimo não for justificado pelos rendimentos tributáveis, não tributáveis, tributados exclusivamente na fonte ou objeto de tributação definitiva;
Se o contribuinte estava obrigado a apresentar a Declaração de Rendimentos, na forma da legislação tributária pertinente, cabível a imposição da multa por atraso da referida Declaração"

Pretende, assim, o Fisco compelir o autuado, ora consulente, ao pagamento de quantia equivalente a $R \$$.............. acrescidos de $R \$$ devido a multa isolada e o juro correspondente a mesma, a saber (...)

Ocorre que não procede a lavratura, bem como a decisão proferida, por ter como supedâneo levantamento efetuado em depósitos bancários, como aqui se positivará sem qualquer dificuldade. Senão, vejamos.

\section{PRELIMINARMENTE}

\section{DO PRINCÍPIO DA IMPESSOALIDADE}

Dispensável tecer considerações quanto a evidente importância do sobredito princípio à Administração, uma vez que a atividade administrativa deve ser destinada a todos os administrados sem determinação de pessoa ou discriminação de qualquer natureza. 
Neste linha, abalizados doutrinadores, tais como WOLGRAN JUNQUEIRA FERREIRA $^{\prime}$, IVAN BARBOSA RIGOLIN ${ }^{2}$, ADILSON ABREU DALLARI ${ }^{3}$, CELSO ANTÔNIO BANDEIRA DE MELLO ${ }^{4}$,

Preciso este entendimento, e não há quem ouse discordar, impõe-se a verificação do ferimento ao suso citado princípio posto que na decisão proferida pela Delegacia da Receita Federal de Julgamento - Fortaleza - CE ao indicar, por extenso, o nome interessado, fez constar desnecessariamente, ao lado, o nome artístico do mesmo.

Ora qual a finalidade deste procedimento? Criar uma distinção entre o artista e o cidadão comum? Um por ser famoso e, em tese, auferir altos rendimentos de seu trabalho deve ser julgado de forma diversa dos demais membros de nossa coletividade? Ser famoso indica sinais exteriores de riqueza que possam influir no julgamento? Como o julgador, de outro Estado, soube que se tratava efetivamente do artista consagrado e conhecido, se poucos o reconhecem pelo seu próprio nome?

Para se evitar estes questionamentos e manter as decisões administrativas incólumes é que se fortaleceu o princípio da impessoalidade, que pelo visto não foi observado no particular, merecendo o julgado, igualmente neste sentido, severas e profundas críticas.

\section{DO MÉRITO}

\section{DO PEDIDO DE INFORMAÇÕES E INICIO DA FISCALIZAÇÃO}

Conforme se extrai do conjunto probatório existente nos autos, verifica-se que o recor- rente, em 18.06.1993 foi intimado pelo Delegado da Receita Federal, o qual apenas solicitava a apresentação das declarações de rendimento de 1989,1990,1991 e 1992.

Neste passo há de se destacar que, antes mesmo de verificar qualquer irregularidade, em atitude arbitrária, olvidando-se do devido processo legal, há na citada intimação uma coação ao contribuinte, ao imputar sua prática como crime contra a ordem tributária, o que se afigura inapropriado em um Estado Democrático de Direito como o nosso.

Por esta visão hodierna, o contribuinte ao invés de ser coagido deve prima facie ter conhecimento dos seus direitos para poder cumprir todas as suas obrigações ${ }^{5}$, pois a atividade primordial do Fisco é orientar os cidadãos e não apenas buscar equívocos cometidos para aplicar multas e aumentar a arrecadação. $O$ binômio orientação/fiscalização há ser pautado no respeito ao contribuinte, jamais se curvar a gula fiscal.

O mestre dos mestres, Aliomar Baleiro, já afirmara no passado:

"O sucesso de qualquer política financeria depende muito da atitude psicológica dos contribuintes, segundo sua consciência cívica e política, na mais pura acepção desta palavra. Os abusos dos legisladores e autoridades fiscais amortecem aquela consciência e levam o espírito do povo a tolerância com os sonegadores e a hostilidade contra o fisco, que só tem a ganhar com a adesão leal dos cidadãos". 6

À evidência, nosso ordenamento jurídico repele atos com estes atributos e a norma cogente do art. 147, do Código Civil é precisa:

Art. 147 - É anulável o ato jurídico:

1 Comentários à Constituição de 1988, Julex, v.1, p. 452.

2 O servidor público na Constituição de 1988, São Paulo, Saraiva, 1989, p. 73.

3 Suplemento Jurídico do Departamento de Estradas de Rodagem do Estado de São Paulo, jan./mar., 1989 , p.8.

4 Curso de Direito Administrativo, $5^{\text {a }}$ ed., ver., atual. e ampl., São Paulo, Malheiros, 1994, p.7.

5 Clélio Barbi, "O processo Fiscal - Teoria e Prática" - 1996, Ed. Icone, p. 210.

6 Aliomar Baleeiro, "Direito Tributário Brasileiro" - Forense, p. 483. 
11 - Por vício resultante de erro. dolo. coaçăo. simulação ou fralde.

Logo. por ter imperado o elemento coativo. 0 ato administrativo que resultou no auto de infraçĩo é anulável, devendo o procedimento ser anulado.

A jurisprudência deságua no mesmo estuário:

Execução Fiscal. Imposto de Renda. Embargos do Executado. Depósitos Bancários.

Comprovados nos autos o fato de que a confissão da divida cobrada resultou de coação. imposta ao contribuinte pelos fiscais autuantes. confirma-se a sentença que conclui pela procedência dos embargos" 1

Após a apresentação da documentação solicitada na intimação acima censurada, é que o Consulente. ém 26.10.1993, recebeu o Termo de Início de Fiscalização, onde se verifica que, somente naquela data os agentes fiscais estavam dando inicio a fiscalizaçào do contribuinte.

Além de iniciar a fiscalização, indevidamente solicitam extratos bancários das contas correntes do Recorrente informadas na declaração de bens do exercício 1992/base 1991 .

Mais adiante, no Termo de Verificação e Intimação, sem data, o próprio auditor fiscal confirma que a fiscalizaçāo encontrava-se sendo efetuada com base nos dados disponíveis e apresentados pelo contribuinte.

Porém esta afirmação não se coaduna com a lavratura do auto de infração, posto que nesse se verifica que a autuação se baseou em três pontos, a saber, sinais exteriores de riqueZa. variação patrimonial e omissão de rendimentos, sendo certo que, nos dois primeiros itens o lançamento tributário foi embasado, tão-somente, em depósitos bancários e apurado de acordo com os extratos indevidamente solicitados.

Ocorre que, conforme restará demonstrado, é ilegítimo o lançamento do Imposto de Renda arbitrado com base apenas em extratos ou depósitos bancários, o que ilide os sinais exteriores de riqueza e a variação patrimonial vislumbrada pelos auditores fiscais. alem disso. uma análise mais atenta da questão e dos documentos existentes comprova que não ocorreu a omissão erigida pela fiscalização $e$ que o contribuinte efetivamente ofereceu, a tributação. os valores percebidos.

\section{DA INVASÃO DE PRIVACIDADE DO CONTRIBUINTE.}

Nossa Lei Maior. promulgada em 1988, determina:

Art. $5^{\circ}$ - Todos são iguais perante a lei, sem distinção de qualquer natureza, garantindo-se aos brasileiros e aos estrangeiros residentes no País a inviolabilidade do direito à vida, à liberdade. à igualdade, à segurança e a propriedade. nos seguintes termos:

$X$ - são invioláveis a intimidade. a vida privada. a honra e a imagem das pessoas, assegurado o direito a indenização pelo dano material ou moral decorrente de sua violação:

XII - é inviolável o sigilo da correspondência e das comunicações telegráficas, de dados e das comunicaçōes telefônicas, salvo, no último caso, por ordem judicial, nas hipóteses e na forma que a lei estabelecer para fins de investigação criminal ou instrução processual penal:

Assim. o indivíduo pode decidir por si. quando, como e até que ponto uma informação sobre ele pode ser comunicada a outrem e conforme preleciona CELSO RIBEIRO BASTOS ${ }^{2}$, ao comentar sobredito mandamento, o direito à privacidade:

"abrange atualmente o de impedir que terceiros, inclusive o Estado e o Fisco tenham acesso a informaçōes sobre o que se denominou 'área de manifestação do ser humano"'.

1 Ap. Cível $n^{\circ}$ 62.632-SP. TRF, 6 ${ }^{\text {a }}$ T, Rel. Min. Américo Luz, julgado em 05.09.83, DJ de 09.12.83.

2 Comentarios à Constituişăo do Brasil: promulgada em 5 de outubro de 1988/ Celso Ribeiro Bastos e Ives Gandra Martins. - São Paulo, Saraiva. v.2. p. 63. 
Destarte. a requisição dos extratos bancários. sob a égide da coação alhures mencionada. jamais poderia ocorrer da forma que os iustres fiscais promoveram, por violarem direito constitucionalmente garantido. logo, não se deve considerar os levantamentos efetuados com base nos extratos bancários.

\section{DO DEVIDO PROCESSO LEGAL E O PRINCÍPIO DA AMPLA DEFESA}

No Termo de Verificação e Intimação verifica-se que or. auditor fiscal solicita ao contribuinte que comprove acréscimos patrimoniais, supostamente a descoberto, referentes aos meses de março e de outubro de 1991.

Nos deparamos, mais uma vez, com outra arbitrariedade. Não há como conceber que o Fisco, apesar das milhares de verificações efetuadas e de autos de infração lavrados, na ânsia arrecadatória, não observe os preceitos legais.

A Lei $n^{\circ} 7.713$, de 22 de dezembro de 1988 , que alterou a legislação sobre a Renda, pela voz do seu artigo $2^{\circ}$, determina:

Art. $2^{\circ}$. - $\mathrm{O}$ imposto sobre a Renda das pessoas físicas será devido, mensalmente, à medida em que os rendimentos e ganhos de capital forem percebidos.

Logo, para que a cobrança se efetue de forma clara e precisa, imprescindível que o Fisco o faça detalhadamente pois ao apresentar apenas o total dos valores questionáveis incorre em flagrante erro, dificultando, ou pior, impossibilitando a defesa do contribuinte.

Ou seja, é ônus do fisco, sob pena de plena nulidade, fornecer precisamente ao contribuinte todas as informações necessárias para que o mesmo possa cotejar a realidade dos fatos com a apuração do auditor fiscal e concordar com o mesmo ou possuir condiçōes de questionar legitimamente o lançamento efetuado e demonstrar os equivocos existentes.

Porém, como efetuar o sagrado direito de defesa se o fisco omite a forma pela qual apurou o valor cobrado e apenas indica um total, que acredita-se ser a soma de outras parcelas.
Como o r. auditor fiscal apurou a suposta variação patrimonial?

Evidentemente. conforme a norma transcrita, deveria ter sido elaborado e demonstrado, mês a mês. os importes ou frações que totalizaram a variação cobrada e ora censurada. bem como a identificação individual dos depósitos bancários.

$O$ direito de defesa, alcandorado em nivel constitucional é um pilar básico da democracia representativa. in rerbis:

Art. 5. - ...

LV - aos litigantes, em processo judicial ou administrativo, e aos acusados em geral são assegurados o contraditório e a ampla defesa. com os recursos a ela inerentes.

Logo, o devido processo legal, com o contraditório e a ampla defesa, constitui vetor do regime instituído pela Carta de 1998, sendo que, no particular, resulta incompatível com a norma em questão o procedimento adotado pelo fisco para demonstrar uma quimérica variação patrimonial.

Os conceitos de contraditório e de ampla defesa, possuem inquestionável liame, até porque o contraditório é um instrumento inerente à ampla defesa.

No processo administrativo a garantia da ampla defesa quer dizer que o contribuinte possui o lídimo direito de manifestar-se sobre toda e qualquer afirmação dos agentes do fisco, que deveräo, à obviedade, ser claras e precisas, sob pena de ferir o princípio constitucional.

Sendo o processo administrativo instrumento para a apuração da verdade material, onde o fisco deve atuar de forma cristalina, sem dúvidas e suposições, motivo pelo qual não se pode prescindir da apropriada comprovação dos dados apurados pela autoridade competente, é defeso ao Fisco arbitrar a existência da renda e a lei somente admite a presunção de omissão de receita que exige, à obviedade, a comprovação efetiva de sua apuração.

Por isso mesmo, na legislação do imposto de renda somente se visualiza duas possibilidades de apurar omissão de receitas: por indício na escrituração ou através de prova concreta. Em qualquer hipótese, não basta a va- 
loração, competirá à autoridade fiscal o ônus de provar claramente a omissão, demonstrando, irrefutavelmente, o elo de ligação entre o valor omitido à tributação e o seu respectivo depósito.

A jurisprudência. diante mencionada lesão, em casos análogos, vem anulando procedimentos como o presente, onde o cerceamento de defesa é o fator preponderante para deixar o administrado desorientado, sem saber do que irá se defender:

"Cerceamento de defesa. Caracterização. Supressão de fase do processo. Ofensa aos princípios do devido processo legal. Ar. $5^{\circ}$, LV, da Constituição da República. Nulidade a partir da deliberação que encerrou a instrução. Recurso Provido para esse fim.

As normas de processo são de direito público cogente. A supressão de fases do processo implica cerceamento de defesa. essa ofensa atinge a Constituição da República, no que concerne aos princípios do devido processo legal e da ampla defesa. E a nulidade é absoluta."'

"Poder de polícia. Processo Administrativo. A Atuação da Administração Pública, no exercício de polícia, ou seja, pronta e imediata, há de ficar estrita aos atos indispensáveis à eficácia da fiscalização, voltada aos interesses da sociedade. Extravasando a simples correção do quadro que a ensejou, a ponto de alcançar a imposição de pena, indispensável é que seja precedida da instauração de processo administrativo, no qual se assegure ao interessado o contraditório e, portanto, o direito de defesa, nos moldes do inciso $L V$, do art. $5^{\circ}$ da Constituição Federal. Não subsiste decisão administrativa que, sem observância do rito imposto constitucionalmente, implique a imposição de pena..."2

Por igual, veda inclusive a quebra do sigilo bancário em procedimento administrativo fiscal:
Tributário. Sigilo Bancário. Quebra com base em procedimento administrativo-fiscal. Impossibilidade.

O sigilo bancário do contribuinte não pode ser quebrado com base em procedimento administrativo-fiscal, por implicar indevida intromissão da privacidade do cidadão, garantia esta expressamente amparada pela Constituição Federal.

Por isso, cumpre as instituições financeiras manter o sigilo acerca de qualquer informação ou documentação pertinente a movimentação ativa e passiva do correntista/contribuinte, bem como dos serviços bancários a ele prestados..."3

No presente, o cerceamento de defesa resta cristalinamente demonstrado, pois o fisco apurou, sem demonstrar como. de qual forma e com que valores, uma hipotética variação patrimonial, infringindo norma legal que determina que sua apuração ocorra mês a mês, e com a devida identificação individual dos depósitos bancários (Lei $\mathrm{n}^{\circ} 7.713 / 88$, art. $2^{\circ}$ ) e impossibilitando, pela ocultação e camuflagem existente, a plena defesa do contribuinte.

Para finalizar o cerceamento de defesa ocorrido, verifica-se a existência de outro Termo de Verificação e Intimação apresentado mais de um ano após o início da ação fiscal, onde se comunica ao contribuinte que foi verificado, em sua declaração de rendimentos apresentada no passado, acréscimo patrimonial e depósitos bancários não justificados pelos rendimentos declarados, solicitando que o contribuinte comprovasse a origem dos rendimentos que justificassem as aplicações.

Mais uma vez o ato administrativo obnubila a aferição do contribuinte, posto que não há demonstrativos mês a mês do suso mencionado acréscimo e identificação individual dos depósitos bancários

1 TJSP - Ac. 126.177-3, São José do Rio Preto, Rel. Celso Limongi, CC, julgado em 17.02.94, JTJ/SP, Lex. 153.

2 STF, RE 153.540-7/SP, Rel. Min. Marco Aurélio, 2a T., julgado em 05.06.95, DJ, de 15.09.95, p. 29.519.

3 STJ, Resp n 37566/RS, Min. Demócrito Reinaldo, DJ de 28.03.1994, p. 6.294 


\section{DA IMPOSSIBILIDADE DE \\ TRIBUTAÇÃO COM BASE ESCLUSIVAMENTE EM DEPÓSITOS BANCÁRIOS}

Inobstante todas as flagrantes nulidades já declinadas anteriormente, a fiscalização se baseou em projeção de extrato bancário do contribuinte, em mais um flagrante equívoco na apuração do aludido débito tributário, face da nulidade absoluta dos elementos tomados como geradores de crédito, em favor da Fazenda Nacional, eis que os valores depositados ou que circularam na conta do contribuinte não são, necessariamente, fonte de recebimento de recursos tributários.

Não existe, porém, e jamais existiu, base legal para exigência fiscal desse jaez.

O tributo em causa, como notoriamente sabido, possui como fato gerador, única e exclusivamente a aquisição de disponibilidade econômica ou jurídica, de renda ou proventos de qualquer natureza (Código Tributário $\mathrm{Na}$ cional), art. 43, ou seja, a aquisiçāo da disponibilidade econômica ou jurídica:

"I - de renda, assim entendido o produto do capital, do trabalho ou da combinação de ambos;

II - de proventos de qualquer natureza, assim entendidos os acréscimos patrimoniais não compreendidos no inciso anterior".

Descabe, por conseguinte, cogitar-se da aquisição de disponibilidade jurídica ou econômica, de renda ou de proventos de qualquer natureza, pela simples constatação da realização de depósito em conta bancária pertencente ao contribuinte, posto que a realização de depósito bancário pode advir de incontáveis razões, sem que qualquer delas represente aquisição de disponibilidade econômica ou jurídica de renda ou de proventos.

E justamente por isso, a lei não agasalha e jamais agasalhou a tributação pura e simples dos depósitos bancários, como fez o Fisco no caso presente.

Ausente o amparo legal, há muito vêm sendo anulado pelo Poder Judiciário procedimentos que se baseiam única e exclusivamente em extratos bancários, originando a Súmula 182 do extinto TRF: "É ILEGÍTIMO O LANÇA-
MENTO DO IMPOSTO DE RENDA ARBITRADO COM BASE APENAS EM EXTRATOS OU DEPÓSITOS BANCÁRIOS".

Noutra réstia, o próprio Poder Executivo baixou o Decreto Lei $n^{\circ} 2.471$, de 01.09.88, que em seu art. $9^{\circ}$ cancela e arquiva procedimentos administrativos como o presente. que tomaram como base valores de extratos ou de comprovantes de depósitos bancários.

"Art. $9^{\circ}$ - ficam cancelados, arquivandose, conforme o caso, os respectivos processos administrativos, os débitos para com a Fazenda Nacional, inscritos ou não como Dívida Ativa da Uniāo, ajuizados ou não, que tenham tido origem na cobrança:

I

VII — do imposto de renda arbitrado com base exclusivamente em valores de extrato ou de comprovante de depósitos bancários".

A jurisprudência é pacífica no sentido de se anular lançamentos, semelhantes à presente hipótese, como se verifica no Acórdão $\mathrm{n}^{\circ}$ 89.01.20986-1 do Tribunal Regional Federal da $1^{\text {a }}$ Região (DF) que é assim ementado:

"Decreto-Lei 2.471 , VII, do art. $9^{\circ}$ súmula 182 do TRF.

1 - O imposto de renda arbitrado, exclusivamente, com suporte em extratos de contas bancárias, já não encontra qualquer suporte legal após a edição do Decreto-Lei $\mathrm{n}^{\circ} 2.471$, de 01.09.88, que com seu artigo $9^{\circ}$ do inciso VII, proibiu o lançamento do IR com base exclusiva nos extratos bancários.

2 - Anteriormente o TRF, na súmula $n^{\circ}$ 1832, decidira: "É ilegítimo o lançamento do Imposto de Renda arbitrado com base apenas em extratos ou depósitos bancários.

3 - Remessa prejudicada por perda o objeto."

A chamada omissão de receita decorrente de movimentação bancária sempre foi examinada com bastante cautela: porque deduzir de meros depósitos bancários - cujas origens podem ser mais variadas - não significa dizer que houve aumento de renda, ganho real de capital, ou sejam, que uma pessoa teve rendimentos, cuja existência omitiu, sendo à toda evidência, mera presunção.

É evidente que o fato de ter o contribuinte depósitos em sua conta-corrente poderia ad 
argumentandum dar ensejo à apuração pelo fisco, o que não se pode admitir é que tal fato. por si só, seja bastante para constituir o crédito tributário, por se presumir tratar-se de rendimentos sem a efetiva comprovação.

A seguir. se reproduz o entendimento no âmbito administrativo, cristalizado em sucessivos arestos proferidos pelo Egrégio $1^{\circ} \mathrm{Con}$ selho de Contribuintes, no sentido de negar validade de créditos tributários. constituídos única e exclusivamente em extratos de contas bancárias, sendo tal procedimento ilegítimo, conforme se vê, in verbis:

"IRPJ — OMISSÃO DE RECEITAS DEPÓSITO BANCÁRIO - Descabe a tributação a título de omissão de receitas, baseada exclusivamente em depósitos bancários, mormente quando a fiscalização tiver agido de maneira simplista, desconsiderando, inclusive os esclarecimentos prestados pelo contribuinte, sem que houvesse elemento seguro de prova ou indício veemente de sua falsidade ou inexatidão."

OMISSÃO DE RENDIMENTOS - SINAIS EXTERIORES DE RIQUEZA - O confronto de débitos em conta corrente apurados através de extratos bancários, com os rendimentos declarados pelo contribuinte, não caracteriza a existência de sinais exteriores de riqueza, face a legislação vigente proibir lançamento com base em extratos bancários." 2

Também exaustivas são as decisōes dos nossos Tribunais, cujas ementas merecem transcrição:

"Tributário. Imposto de Renda Depósitos Bancários. Decreto $n^{\circ} 58.400$, art. 55, e; Decreto $n^{\circ} 76.186 / 75$, art. 39 ;

I - O sinal exterior de riqueza, os depósitos bancários que se evidenciaram a renda auferida ou consumida pelo contribuinte deve ser o marco inicial da investigação do fisco, e não o objetivo final. Impossibilidade de tributação incidir simplesmente sobre depósitos bancários." 3

"TRIBUTÁRIO - Imposto de Renda Lançamento "ex-officio" Omissão de receitas presumidas - Extratos bancários - Descabimento - Embargos à execução.

$I$ - É ilegítimo o lançamento do imposto de renda arbitrado com base em depósitos bancários.

II - Entendimento Jurisprudencial, cristalizado no verbete da Súmula $n^{\circ} 182$ do extinto Tribunal Federal de Recursos, posteriormente consagrado legislativamente, pela edição do Decreto-Lei $n^{\circ} 2.441 / 88$.

III - Sentença reformada para determinar o cancelamento do débito exeqüendo e condenar o exequiente em custas processuais e honorários advocatícios fixados em $10 \%$ (dez por cento) sobre o valor atualizado da dívi$d a " .4$

$\mathrm{O}$ Egrégio TRF $-2^{\mathrm{a}}$ Região no $\mathrm{HC} \mathrm{n}^{\circ}$ 96.021 1037-6/RJ, da $2^{\mathrm{a}}$ Turma, julgado no daí 21 de maio de 1996, cujo relator foi o eminente Desembargador ALBERTO NOGUEIRA, onde ficou consolidado o entendimento que no campo penal em denúncia baseada $\mathrm{em}$ mera movimentação financeira não pode ser taxada de séria, pois a legislação do imposto de renda não exige que o contribuinte tenha uma escrituração contábil, conforme a seguir transcrito:

"DIREITO PENAL E TRIBUTÁRIO. DENÚNCIA APOIADA EM AUTO DE INFRAÇÃO EM QUE SE APURA FALTA DE RECOLHIMENTO DE TRIBUTO - LEI N 8.137, ART. $I^{\circ}$ INCISO I...

AUSÊNCIA DE INDICAÇĀO DAS CIRCUSTÂNCIAS EM TEMPO, LUGAR E OBJETO REFERENTE À SONEGAÇÃO APONTADA. HABEAS CORPUS CONCE-

1 Acórdão n ${ }^{\circ}$ 103-11.723, publicado no DOU em 16.02.1995, fls. 2047

2 Acórdão n 102-29.693, publicado no DOU em 27.06.1995, fls. 9421.

3 TRF, remessa "ex-officio" 77.266-SP, Relator Ministro Carlos Mário Velloso.

4 TRF/3 ${ }^{\mathrm{a}}$ Região, $3^{\mathrm{a}} \mathrm{T}$, Apelação Cível n 89.03.18161-1/SP, Relator Juiz Márcio Moraes, publicado em 03.02.92, DOE, p. 159, Caderno I. 
DIDO PARA TRANCAR A AÇÃO PENAL. À UNANIMIDADE.

1 - A legislação do imposto de renda não exige, como obrigação acessória que o contribuinte, pessoa física mantenha uma escrituração contábil.

2 - Cobrança coativa é decorrente de um movimento que tomou corpo, primeiramente. nos Estados Unidos, veio se espalhando pela América Latina e atingiu o Brasil. É o chamado "Movimento da Lei e da Ordem".

3 - Não denuncia para cobrar. A denúncia é no sentido de salvaguardar o interesse da sociedade, preservar a cidadania e, não, atormentar o cidadão.

4 - O auto de infração é uma peça prévia a discutir, em que o contribuinte tem o direito constitucional assegurado ao devido processo legal - Art. $5^{\circ}, L I V$ e $L V$ da CF/88, REGULADO PELO DEC 702357/2.

Hábeas Corpus concedido para trancar a ação penal, à unanimidade. (Grifos nossos)."

Ainda, apenas para ilustrar, basta se constatar o robusto voto no Acórdão $\mathrm{HC} \mathrm{n}^{\circ}$ 96.02.08199-6/RJ, também do TRF $2^{\text {a }}$ Região, julgado em no dia 22 de julho/96, da lavra do eminente Desembargador CASTRO AGUIAR, cuja hipótese é a de repudiar lançamentos feitos com base em extratos ou depósitos bancários:

"PENAL - IMPOSTO DE RENDA APURAÇÃO DE CRÉDITO TRIBUTÁRIO CRIME DE SONEGAÇÃO FISCAL - PAGAMENTO DE DÉBITO ANTES DO RECEBIMENTO DA DENÚNCIA - LANÇAMENTO ARBITRADO COM BASE EM EXTRATOS OU DEPÓSITOS BANCÁRIOS.

I - De acordo com o art. 34 da Lei ${ }^{\circ} 9.249$, de 26.12.95, extingue-se a punibilidade dos crimes definidos na Lei $n^{\circ} 8.137$, de 27.12.90, e na Lei 4.729, de 14.7.65, quando por agente promover o pagamento do tributo, ou contribuição social, inclusive acessórios, antes do recebimento da denúncia.

II - Se há comprovação de pagamento anterior à denúncia, há ausência de justa causa para o processo penal.
III - É ilegítimo o lançamento de imposto de renda arbitrado com base apenas em extratos ou depósitos bancários. (Súmula $\mathrm{n}^{\circ} 183$ do TRF).

IV - Ordem concedida.

(...)

"Ora, a paciente está submetida aos rigores da ação penal, porque o fisco entendeu também que sonegara tributos, uma vez que não conseguira justificar a origem dos depósitos bancários efetuados em suas contas-correntes. Alega a paciente, contudo, que os depósitos existentes em suas contas decorreram de mera movimentação de outros bancos ou de depósitos efetuados por seu marido.

Tem-se entendido que o lançamento efetuado com base em depósitos bancários é inteiramente inconsistente, uma vez que a existência dos mesmos não autoriza admitir-se que o contribuinte tenha obtido disponibilidade econômica ou jurídica, fato gerador do tributo. Nem todo depósito bancário é inteiramente inconsistente, uma vez que a existência dos mesmo não autoriza admitir-se que o contribuinte tenha obtido disponibilidade econômica ou jurídica, fato gerador do tributo. Nem todo depósito bancário é inteiramente inconsistente, uma vez que a existência dos mesmos não autoriza admitir-se que o contribuinte tenha obtido disponibilidade econômica ou jurídica, fato gerador do tributo. Nem todo depósito bancário corresponde a renda do titular da conta. De tão tranquiila, a matéria encontra sumulada: "É ilegítimo o lançamento do imposto de renda arbitrado com base apenas em extratos ou depósitos bancários" (Súmula 182 do TFR). Saliente-se que o Decreto-Lei $n^{\circ} 2.471$, de 01.09.88, no seu art. $9^{\circ}$, chegou a determinar o cancelamento de todos os débitos para com a Fazenda Nacional, ajuizados ou não, que tenham tido origem na cobrança de impostos de renda arbitrados exclusivamente em valores de extratos ou de comprovantes de depósitos bancários.

Reconheço, pois, a falta de justa causa para o prosseguimento da presente ação penal, pelo que determino seu trancamento, sem préjuízo de que outra ação, no futuro, possa ser proposta, mediante novos elementos e novas provas. 
Isto posto. concedo a ordem de hábeas corpus. para decretar o trancamento da ação penal.

É como o voto“. (g.n.)

Nessa moldura. o sempre lembrado Tribunal Federal de Recursos, que deu lugar ao atual STJ, não teve dúvida em reprimir fiscalizaçōes como as que ocorreram no presente caso, através de uma jurisprudência firme e atenta a evitar verdadeiro excés de pouvoir.

“Tributário. Imposto de Renda. Lançamento ex-officio. Depósitos bancários. É ilegítimo o lançamento ex-officio do imposto, tornando-se como configuradora desta a simples existência de depósito bancário. Precedentes." 1

"Imposto de Renda - Lançamento "ex-officio" - Arbitramento dos rendimentos tributáveis com base apenas em depósitos bancários - Procedimento fiscal ilegítimo.

Não é possível considerar como lucro as importâncias depositadas em contas bancárias, sem pelo menos deduzir os saques efetuados nas mesmas contas - Confirmação de sentença que julgou procedentes embargos do devedor, elevando-se os honorários de advogado de 3 para $10 \%$ sobre o valor do débito cobrado na execução fiscal." 2

Abra-se parênteses para enfatizar a posição uníssona da doutrina pátria, iniciando-se pelo Mestre GILBERTO DE ULHÔA CANTO, ${ }^{3}$ que, em laço de felicidade declina o direito infraconstitucional, a posição dos cientistas do direito e a jurisprudência que melhor espelha situações como a debatida na presente consulta::

"São freqüentes os casos em que as autoridades tributárias tentam, a partir da soma de depósitos feitos em contas bancárias do contribuinte pessoa física ao longo de determinado período de tempo, estabelecer um montante global que constituiria a verdadeira dimensão dos rendimentos por ele auferidos no ano-base. pretendendo, em conseqüencia, cobrar imposto de renda sobre a diferença entre esse montante e dos rendimentos declarados no mesmo exercicio.

De qualquer maneira, trata-se de uma presunção de percepção de rendimento baseada na circunstância de haver evidência de disponibilidade sabre acréscimo patrimonial, que estará na raiz dos sinais exteriores de riqueza como declara a lei. É uma presunção legal do tipo relativa, ou 'iuris tantum', porque cede à prova contrária, que no caso seria a da origem dos recursos evidenciados pela renda auferida ou consumida em rendimentos não tributados ou tributados só na fonte. $\mathrm{Na}$ medida em que não houver essa prova como manda a lei, a presunção seria aceitável desde que a existência de renda auferida ou consumida, e como base de cálculo o montante a ser arbitrado, sujeito ao contraditório exigido pelo art. 148 do CTN.

Mas, admitindo-se como válida a praesumptio legis', há que considerar o modo da sua autuação em cada caso concreto. E é como aplicação da hipótese que as autoridades fiscais têm tentado identificar rendimentos representativos dos sinais exteriores de riqueza auferida ou consumida em situaçōes nas quais apenas se comprovou a existência de depósitos bancários em montantes que excedem os rendimentos declarados, 'como se eles fossem, por si sós, a evidência que a lei requer'.

...

O problema, entretanto, não é quantitativo. Trata-se de saber se depósitos bancários constituem, de per si sós, evidência de rendimentos auferidos ou consumidos pelo contribuinte que os efetuou, e a resposta afirmativa à pergunta é necessária para que se possa admitir que a lei foi aplicada em cada caso concreto, já que ela exige que haja a) sinais

1 TFR, 2" Seção, E.I. Ap. Cível 72.975-RJ. Rel. Min. Justino Ribeiro, DJU de 04.11.82.

2 TFR - AC 51.591/SP (3409910), Rel. Min. Armando Rolemberg, julgado em 24.11.82.

3 in "Cademo de Pesquisas Tributárias" $\mathrm{n}^{\circ}$ 9. Ed. Res. Tributária e Centro de Estudos de Extensão Universitária, São Paulo, 1984, pp. 20/26 
exteriores de riqueza, b) que evidenciem a existência de rendimentos auferidos ou consumidos, c) omitidos na declaração, isentos ou taxados só na fonte. Não basta que tenha havido sinais exteriores de riqueza; são ainda necessários os dois outros requisitos indicados em b) e c).

$O$ mero fato de certo contribuinte haver efetuado depósitos em banco no decurso do período-base não é, por si só, comprobatório de que ele tenha auferido rendimentos tributáveis. Para que a presunção que a lei formula ocorra é necessário que entre o fato verificado e à conseqüência da tributação exista nexo da evidência de auferimento de rendimentos omitidos na declaração, e sujeitos a imposto ainda não recolhido. Como muito bem salientado por LAURO LIMORÇO ("Informativo Dinâmico" " ${ }^{\circ} 1.390$, de 27.V.1983, p. 612) a lei fala em "evidência de renda", $e$ não "evidência de depósito", pois este poderá decorrer não só de proventos recebidos, mas de outras muitas causas.

Noutros julgados, entretanto, o tribunal foi mais incisivo na repulsa à pretensão fiscal. Eis a ementa do acórdão proferido em 31.3.1983 na Apelação Cível $n^{\circ} 68.350$, relatada pelo Ministro MIGUEL JERÔNIMO FERRANTE:

'Embargos do devedor. Depósito bancário.

Os depósitos bancários, embora possam refletir sinais exteriores de riqueza, não carac. terizam, por si sós, rendimentos tributáveis. Para tanto, faz-se mister a demonstração do aumento patrimonial e do aumento da receita de modo inequívoco. Insustentabilidade do procedimento fiscal que se esteia em mera presunção, resultante da comparação entre soma dos depósitos bancários e o montante dos rendimentos declarados. Incomprovados os pressupostos do lançamento, posto que a prova pericial está a militar contra a pretensão exeqüenda, na medida em que informa os seus suportes fáticos, retirando-lhe a certeza de sua validade. Sentença reformada. Apelação provida. '( "Revista do Tribunal Federal de Recursos", vol. 85, p. 145)'.

Nas considerações de seu voto o reator mostrou que 'a autoridade lançadora teria de provar de modo categórico a omissão de receita efetivamente recebida, e só depois disso poderia, já lastreada na certeza da ocorrência do fato gerador, buscar, no montante dos depósitos, compulsado com bom senso, a base de incidência do imposto cujo fato gerador já estivesse comprov'ado'.

Pelo exposto, 'entendo que a existência de depósiros bancários em montantes excedentes dos rendimentos declarados não configura, de per si só, a existência de fato gerador do imposto de renda devido pelas pessoas fisicas como sinal exterior de riqueza que evidencie a renda auferida ou consumida pelo contribuinte'. Os próprios textos legais pertinentes falam em 'evidência' de renda auferida ou consumida, 'o que faz pressupor a necessidade de prova evidente de auferimento ou consumo de renda; e isso, a só existência de depósitos bancários não é.'."

E seguindo a órbita do Conselho de Contribuintes do Ministério da Fazenda, ilustres publicistas sublinham:

"A própria administração - pela voz do Conselho de Contribuintes do Ministério da Fazenda - já curvou-se às exigências contempladas nessa particular hipótese normativa:

'Depósitos bancários de origem não comprovada, embora possam ser tomados como sinais exteriores de riqueza, não caracterizam rendimento tributável na cédula $\mathrm{H}$. A formulação incompleta do artigo 55 , letra ' $\mathrm{e}$ ', do Decreto $n^{\circ} 76.186 / 75$, não prevê a percentagem que deve ser aplicada à base ou suporte, para efeito do arbitramento que alude. Esse elemento não pode ficar ao talante da administração Provido Recurso'. (Acórdão n ${ }^{\circ}$ 1.42699, de 24.10.77 - $4^{a}$ Câm. Do $1^{\circ}$ C.C., votação unânime).

No mesmo sentido o teor dos acórdãos 1.42.705 e 1.4-2.702, ambos de 24 de outubro de 1977. Curioso que, neste último, despachando recurso hierárquico, o próprio Ministro da Fazenda negou-se a reformar o acórdão referido, pretensão deduzida com base em parecer continente de estranhissima argumentação, como se vê, verbis: 
'Realmente 'não há norma legal equiparando os depósitos bancários inexplicados a rendimentos tributáveis'. nem caracterizando esse mesmo depósito como fato gerador do imposto de renda. Por outro lado, o arbitramento de rendimentos, com base nos sinais exteriores de riqueza, é método de dificil implementação. 'pela ausência de parâmetros legislados' e diversidade de um caso para outro.

Entretanto, 'essas circunstâncias não obstam, a nosso ver, a tributação dos rendimentos', omitidos à declaração, como no caso presente, 'espelhados em depósitos bancário$s$ ' incontrastavelmente incompativeis com os rendimentos declarados" (grifos nossos) (Parecer $n^{\circ} 231 / 78$, de 21.06.78, no processo $\left.n^{\circ} 825-51.441 / 76\right)$.

Por isso a limpidez do entendimento fazendário melhor se desume, quando considerado o expressivo trecho do voto vencedor, proferido no acórdão $n^{\circ}$ 1.4-2701, de 1977, da mesma $4^{a}$ Câmara do $1^{\circ}$ Conselho de Contribuintes, que vale a pena reproduzir, in verbis:

'Em acórdão proferido por esta mesma Câmara, no recurso $n^{\circ} 28853$, forcejamos por demonstrar o defeito técnico que inibe a aplicação do suso mencionado art. 55, letra " $e$ ", exibindo que a despeito de haver base para o arbitramento, este se tornava impossível, à míngua de expresso parâmetro para a escolha da alíquota ou taxa. Com admitir-se a eleição indiscriminada de certa percentagem, ao talante do agente administrativo competente, estaríamos ingressando no mar revolto das soluçōes extra-legais, sobre violar cânones sobranceiros que norteiam a atividade impositiva, no rígido e exaustivo sistema constitucional tributário brasileiro. Isto porque o lançamento é ato vinculado, em que a autoridade deve pautar o procedimento em termos de estreita aderência ao texto normativo correspondente, não lhe sendo outorgada qualquer margem de liberdade criadora, seja para constranger o plano de incidência da regra, quer para expandir seus efeitos, dilargando o campo específico de sua aplicação. Nesse sentido, aliás é peremptório nosso direito positivo, pois alude até à responsabilidade funcional do agente, para dar alcance $e$ dimensão à figura do lançamento, como atividade vinculada e obrigatória.

$\dot{E}$ o princípio da estrita legalidade, ou da tipicidade absoluta, tal qual consagrados nas províncias do Direto penal.

Em formulação sumária é aplicável o discutido preceito, por carecer de entidade imprescindivel à sua composição interior, justamente aquela que permitiria determinar; com precisão e clareza o 'quantum' devido, nas hipóteses de existência de sinais exteriores de riqueza.

Quanto à capitulação inscrita no instrumento decisório e enfatizado nas respectivas intimações, a mais absurda parece ser a exigência fiscal. Falar-se em acréscimos de patrimônio sem dados comparativos, sem elementos que permitam o confronto dos saldos no derradeiro termo de dois exercícios subconsecutivos, é versar tema desconhecido. com instrumentos inadequados e de forma imprópria. Está niveamente claro que os de. pósitos esquadrinhados pelo Fisco não integram, enquanto tais, o resultado final do patrimônio do recorrente naqueles dois exercicios. Como cotejá-los? Por que, então, a referência a aumento de patrimônio?

Mas, ainda que não bastassem as objugatórias, e o versículo é suficientemente claro ao indicar que cabe à repartição lançadora comprovar a ocorrência do acréscimo, em desconformidade com os valores declarados pelo contribuinte. Esta providência também inexistiu. No corpo dos autos não há qualquer expediente que signifique, em esforço de patrimônio do sujeito passivo houvera aumento, em descompasso com os rendimentos declarados. Procurou, isto sim explicação para certos depósitos bancários que, quando muito, e considerados juntamente com os saques efetuados na conta corrente, poderiam servir de elementos comprovantes do saldo global no encerramento do ano base.

Aqui, por todos os títulos, operou a autoridade de primeiro grau de maneira atópica, elegendo, canhestramente, como base de imposição, dispositivo que não hospeda as circunstâncias fácticas que compõem o acontecimento, objeto da apressada exigência tributária. 
Sopesados os motivos que tolhem a incidência dos mandamentos sugeridos na presente ação fiscal, e outra razão de cabedal relevo se levantaria para empecer o crédito já formalizado: a inequívoca mudança do critério jurídico do lançamento.

Realmente, é doutrina assente em copiosa jurisprudência, e posiçâo segura, nos mais apontados tributaristas, que o lançamento não pode sofrer mutação numérica, suscitada por erro de direito. Da mesma forma, e ainda que permaneçam idênticos os valores reclamados, não é dado à Administração modificar os supedâneos da pretensão fiscal, sob a pena de comprometer o direito de defesa que a legislação prevê e cerca de inusitadas garantidas, acoimando de nulidade os atos praticados sem atinência a tais prerrogativas do sujeito'.

De tudo, transparece a evidência das sensiveis insuficiências do dispositivo legal em questão. E mesmo que assim não fosse, certo é que - no procedimento que tende ao lançamento - à administração, e só a ela, inquestionavelmente cumpre percorrer as fases lógicas componentes do iter legalmente contemplado no referido artigo $9^{\circ}$. Descabe, pois, imputação aleatória, afirmando a identificação do eventual valor do sinal exterior de riqueza - que no caso seria o montante dos depósitos bancários - ao suposto montante do rendimento arbitrado (e tributável), baseado em meros depósitos bancários."

Assim sendo, a autuação fiscal feita sobre a movimentação bancária do consulente é natimorta, por ser inadmissível como meio de aferição de ganho de capital, como exaustivamente demonstrado pela jurisprudência colecionada na presente peça, devendo ser anulado o procedimento que impôs tributação ao contribuinte por este motivo.

A impossibilidade de tributação com base exclusivamente em depósitos bancário é tão bradante que no ofício $n^{\circ} 528 / 96$, do Delegado da Receita Federal, para a Procuradora da República, solicita que 'no encaminhamento de cópias de extratos bancários relacionados com procedimentos fiscais a serem instaurados por esta unidade administrativa, sejam também anexadas cópias dos respectivos cheques emitidos pelos contribuintes. Tal solicitação se torna ncessária em virtude de sucessivas decisōes do Egrégio Conselho de Contribuintes que, apreciando feitos fiscais amparados tão-somente, em extratos bancários, tem-se manifestado pela improcedencia do lançamento. com a argumentação básica de que seria necessário verificar se os gastos efetuados pelos contribuintes foram superiores à renda declarada".

Torna-se oportuno registrar que, mesmo com o advento da Lei $n^{\circ} 8.021 / 90$, que veio a autorizar o arbitramento de rendimentos com base na renda presumida, inclusive partindo-se de "depósitos ou aplicações realizadas junto a instituições financeiras, quando o contribuinte não comprovar a origem dos recursos utilizados nessas operações (art. $6^{\circ}, \S$ $5^{\circ}$ ) não se permite à autoridade lançadora restringir-se unicamente ao levantamento de depósitos bancários e taxá-los sumariamente, conforme se verifica no caso dos autos.

$E$ isso se extrai clara e inquestionavelmente da letra do $\S 6^{\circ}$, do art. $6^{\circ}$, do referido diploma, que sentencia e adverte:

" $\$ 6^{\circ}$. Qualquer que seja a modalidade escolhida para o arbitramento, SERÁ SEMPRE LEVADA A EFEITO AQUELA QUE MAIS FAVORECER O CONTRIBUINTE".

$O$ arbitramento com base em depósitos bancários de origem não comprovada é apenas uma alternativa cogitada pela Lei $n^{\circ} 8.021 / 90$ (ART. $6^{\circ}, \S 5^{\circ}$ ), que antes, entretanto, fixa-se nos chamados "sinais exteriores de riqueza" (art. $6^{\circ}$, caput), definindo como tal "a realização de gastos incompatíveis com a renda disponivel do contribuinte" (art. $6^{\circ}, \S 1^{\circ}$ ), que por seu turno se constitui da "receita auferida, diminuída dos abatimentos e deduções admitidos pela legislação do Imposto de Renda em vigor e do Imposto de Renda pago pelo contribuinte" $9^{\circ}$ art. $6^{\circ}, \S 2^{\circ}$ ).

Impõe-se ao Fisco, portanto, proceder ao arbitramento primeiro em face dos "sinais exteriores de riqueza” e, depois. Com base nos depósitos bancários, verificando, a seguir, qual dessas modalidades é a mais favorável ao contribuinte e procedendo, ao final, ao lan- 
çamento segundo essa modalidade mais favorável.

Nesse sentido, por sinal. recente decisão unânime da $6^{a}$ Câmara do Primeiro Conselho de Contribuintes do Ministério da Fazenda. relativa ao Recurso $n^{\circ} 03.499$, no Processo $n^{\circ}$ 13710.000074/94-81, conforme Acórdão n ${ }^{\circ}$ 106-08.179, assim ementado:

"IRPF - Omissão de Rendimentos - Sinais Exteriores de Riqueza - Lançamento COM BASE EM DEPÓSITOS BANCÁRIOS - O art. $6^{\circ}$ da lei $n^{\circ} 8.021 / 90$ autoriza o arbitramento dos rendimentos com base em depósitos bancários ou aplicações financeiras, quando o contribuinte nâo comprovar a origem dos recursos e o Fisco comprovar sinais exteriores de riqueza, caracterizados por realização de gastos incompatíveis com a renda disponível do contribuinte."

Totalmente indevida, pois, a autuação fiscal.

\section{DA INEXISTÊNCIA DE OMISSÃO DE RENDIMENTOS RECEBIDOS}

Conforme destacado no pórtico do presente parecer, a estouvada fiscalização apurou uma "suposta omissão de rendimentos recebidos de pessoa juridica, decorrente de trabalho sem vínculo empregaticio, conforme..." (fls. 04)

Ocorre que, baseado em decisão constante dos autos, verifica-se que o contribuinte, em escorreita atitude não vislumbrada pelo agente fiscal, efetivamente ofereceu todos os valores a tributação, conforme se depreende da declaração de rendimentos entregue em 14.09.1993, constante dos autos.

Ao se cotejar os valores informados na declaração de rendimentos e os apurados pelo fiscal, infere-se que ocorreu apenas a omissão de valores ínfimos, o que foi corroborado pela decisão de primeira instância.

Desta forma lídima a redução da variação patrimonial apontada na decisão da impugnação apresentada ao auto de infração lavrado pela ação fiscal.

\section{DA AUSÊNCIA DE TIPICIDADE E SINAIS EXTERIORES DE RIQUEZA}

Ampliando o conjunto de falhas contidas no procedimento fiscal em apreço, verifica-se a completa ausência de tipicidade, posto que, na capitulação dos dispositivos infringidos. mencionam-se vários artigos que jamais podem ser violados por qualquer contribuinte.

As supostas infrações elencadas, conforme já mencionado, foram as contidas nos arts. $1^{\circ}$ a $3^{\circ}$ e parágrafos e art. $8^{\circ}$, da Lei $n^{\circ} 7.713 / 88$; arts. $1^{\circ}$ a $4^{\circ}$, da Lei $n^{\circ} 8.134 / 90$; art. $6^{\circ}$ e $\S \S$, da Lei $n^{\circ} 8.021 / 90$.

Examinando-se cada um desses dispositivos, verifica-se:

- os artigos $1^{\circ}$ a $3^{\circ}$ e parágrafos da Lei $n^{\circ}$ 7.713/88 estabelecem regras gerais de incidência do imposto, não residindo neles, portanto, o fundamento específico da autuação;

- o art. $8^{\circ}$. da mesma lei, regula o recolhimento mensal do imposto pela própria pessoa física - carnê leão.

- os artigos $1^{\circ}$ a $4^{\circ}$. da lei $n^{\circ} 8.134 / 90$, traçam, da mesma forma, normas gerais de tributação do imposto das pessoas físicas e, sobretudo, servem para esclarecer que a elas se aplica o regime de caixa;

- finalmente, no art. $6^{\circ}$ e parágrafos, da Lei $n^{\circ} 8.021 / 90$, foi o ilustre fiscal buscar a inspiração para a violência perpetrada de vislumbrar riqueza na pobreza, lavrando auto de infração notoriamente ofensivo à lei.

Ora, mencionados comandos normativos, não amparam a inquinada pretensão físcal.

Da leitura do art. $6^{\circ}$. da Lei $n^{\circ} 8.021 / 90$, infere-se que o dispositivo veio estabelecer um processo de arbitramento com base em renda presumida (presunção legal) a partir de sinais exteriores de riqueza.

Ocorre que este processo se decompõe, necessariamente, nas seguintes etapas:

a) determinação da renda tributável:

b) identificação dos gastos do contribuinte e demonstração de sua incompatibilidade com a renda disponível;

c) demonstrada essa incompatibilidade, notificação explícita ao contribuinte para instau- 
rar o procedimento de arbitramento daqueles gastos com bases nos preços de mercado praticados à época de sua realização ou, subsidiariamente, com base nos depósitos ou aplicações realizados junto a instituições financeiras. cuja origem, não for comprovada:

Assim encontra-se erigida a lei, devendo a autoridade tributária proceder no processo legal estipulado, pois ao se afastar deste, vicia de nulidade seu ato, agredindo o preceito insculpido no art. 142, parágrafo único do Código Tributário Nacional, segundo o qual, a atividade administrativa do lançamento é vinculada.

Além do mais, para que possa haver presunção de riqueza exteriorizada, é indispensável, como indica a própria acepção do termos, que se tratem de gastos expressivos opulentos, magnificentes, o que não ocorre no presente caso.

Inquestionavelmente, apesar do auditor fiscal não ter demonstrado mês a mês a origem dos valores apontados, verifica-se que os próprios rendimentos declarados fornecem elementos que suportam o pagamento efetuados nos negócios mercantis que erigiram a suposta variação patrimonial.

Logo, se patenteia a descaracterização da acusação de sinais exteriores de riqueza não estando devidamente comprovados, como deveriam, os gastos incompatíveis com a renda disponível.

\section{DOS JUROS E TAXA SELIC.}

Além do mais, relativamente à cobrança de juros de mora intentada pelo Auto de Infração, no que se refere a juros calculados acima do limite de $1 \%$ ao mês, ou melhor, calculados em função da evolução da Taxa Referencial Diária - como fez o Fisco, de acordo com o que revelam os demonstrativos correlatos integrantes da autuação impugnada - a pretensão fazendária esbarra e frustra-se completamente, diante do que reza o art. $161, \S 1^{\circ}$. do Código Tributário Nacional.
E quanto à questão de cobrança de correção monetária também em razão de diferenciais da antiga TR e da atual Selic - que, tudo lev'a a crer, se acha igualmente englobada na exigência fiscal sob foco, impende lembrar a gritante inconstitucionalidade em que com isso milita o Fisco.

No passado, a Lei $\mathrm{n}^{\circ} 8.218 / 91$, instituiu a Taxa Referencial - TR/TRD como juros de mora incidente sobre os débitos do contribuinte (art. $3^{\circ}, 1$ ).

Posteriormente, foi editada a Lei $\mathbf{n}^{\circ}$ $8.981 / 95$ que determinou fossem os referidos juros de mora equivalentes a Taxa Média Mensal de Captação do Tesouro Nacional relativa a Dívida Mobiliária Interna Federal (art. 84, 1)

Atualmente, os multicitados juros são equiivalentes a taxa Selic-Sistema Especial de Liquidação e de Custódia para Títulos Federais. conforme determina o art. 13 da Lei ${ }^{\circ}$ 9.065/95.

Assim sendo, da simples leitura dos citados dispositivos, pode-se concluir, com facilidade, que os tais juros moratórios são equivalentes às taxas financeiras, ou seja, decorrentes da variação de títulos públicos ocorridas no mercado.

Repita-se: tais juros refletem a variação do rendimento do valor de mercado de diversos títulos públicos, não possuindo, pois, a natureza indenizatória típica do Direito Tributário, mas sim natureza remuneratória própria dos juros do mercado financeiro!

Ora não há como exigir do contribuinte $30,52 \%$ (trinta vírgula cinqüenta e dois por cento) em novembro de 1991 de juros moratórios/TR. Considerando-se que no mês de outubro de 1991 a TR foi $19,77 \%$ (dezenove vírgula setenta e sete por cento), como imputar uma diferença/acréscimo de mais de $10 \%$ (dez por cento) mês a título de juros moratórios pela simples ocorrência de determinado fato político que resultou na queda abrupta da cotação dos títulos públicos negociados?

Não se pode olvidar, como acima registrado, que o Código Tributário Nacional, desde 1966 , fixa no art. $161, \S 1^{\circ}$ os juros de mora 
à taxa de $1 \%$ (um por cento) ao mês. o que foi ratificado pela Constituição Federal de 1988 no art. $192 . \$ 3^{\circ}$ ao limitar as taxas de juros reais em até $12 \%$ (doze por cento) ao ano.

Nesse sentido, com a clareza e brilhantismo que lhe é peculiar. o eminente Desembargador do TRF/2 $2^{a}$ Região PAULO ESPÍRITO SANTO, assim conduziu seu voto, acompanhado por unanimidade pelos membros da $2^{\mathrm{a}}$ Turma, verbis:

“(...) em nosso sistema os juros moratórios não podem ultrapassar os $1 \%$ ao mês. É o que resulta de interpretação sistemática do preceito do art. $161, \S 1^{\circ}$ do C.T.N., com os demais comandos limitando os juros, inclusive na Constituição." I

Ademais, como é de curial sabença, o Pleno do E. SUPREMO TRIBUNAL FEDERAL declarou na Ação Direta de Inconstitucionalidade $n^{\circ}$ 493-0/DF, cuja decisão tem eficácia erga omnes e efeito vinculante, que a Taxa Referencial é inconstitucional ${ }^{2}$.

$\mathrm{Na}$ mesma réstia encontra-se sendo discutida atualmente, no SUPERIOR TRIBUNAL DE JUSTIÇA, no âmbito de incidente de inconstitucionalidade, a aplicação da mencionada taxa SELIC na seara tributária, sendo que o relator do processo Ministro FRANCIULLI NETTO, em voto admitido pela unanimidade da Segunda Turma, demonstrou a insustentabilidade da aplicação da referida taxa na seara tributária, por total ausência de lei neste sentido, uma vez que nesta área de direito público vige o princípio da estrita legalidade (REsp. $n^{\circ} 215.881 / P R$ ).

Diante do exposto, conclui-se que é inconstitucional a cobrança de juros de mora equivalentes às taxas (altamente variáveis) de remuneração de títulos públicos, mormente quando estas ultrapassam o limite previsto no C.T.N. e na Constituição Federal.
Mas não é só: os juros incidem sobre juros! Ora Exa, isso é anatocismo proibido em lei (Decreto $\mathrm{n}^{\circ} 22.626 / 33$, ratificado pelo CTN, veda a capitalização mensal dos juros), tanto é assim que a Súmula 121 do E. Superior Tribunal de Justiça dispõe que:

SÚMULA 121 STJ - "É vedada a capitalização de juros, ainda que expressamente convencionada."

Logo, conclui-se que os juros só poderão incidir sobre o valor do principal corrigido e não sobre os próprios juros, devendo o Fisco comprovar a sua inexistência, demonstrando, de forma detalhada a memória de cálculo que sustenta a exigência fiscal lavrada na época e sua atualização até a presente data, sob pena de ferir o princípio da ampla defesa já mencionado em tópico específico.

Quanto a correção monetária, muito pouco ou quase nada tem a autora a requerer, senão a aplicação, no interstício em questão, dos índices oficiais amplamente reconhecidos pelo Poder Judiciário.

\section{CONCLUSÃO}

Ao lume destas considerações, apoiadas em doutrina de indiscutível jaez, bem como na melhor jurisprudência, s.m.j., não restam dúvidas que os ilustres fiscais não observaram de forma fidedigna os preceitos ensejadores da autuação em análise, que, desta forma, dever ser declarada nula, por ser construída sob a égide de presunções.

É o que nos parece.

MAURO ROBERTO GOMES DE MATTOS

\section{CARLOS HENRIQUE DA FONSECA}

1 Apelação Cível $n^{\circ} 145864$ AC/RJ (Proc. $n^{\circ}$ 97.02.27040-5), relatada pelo eminente Desembargador Paulo Espírito Santo, D.J. 20/04/99, $2^{\mathrm{a}}$ Turma do TRF/2a Região.

2 Ação Direta de Inconstitucionalidade $n^{\circ} 493-0 / D F$, relatada pelo eminente Ministro Moreira Alves, D.J. 04/09/92, STF. 